\title{
Characterization of bacteria associated with nodules of two endemic legumes of Algeria, Hedysarum naudinianum and $\boldsymbol{H}$. perrauderianum
}

\author{
Asma Torche - Hayet Benhizia • Riccardo Rosselli • Ottavia Romoli • Marina Zanardo • \\ Enrico Baldan • Sara Alberghini • Alessandra Tondello • Barbara Baldan • \\ Amar Benguedouar • Andrea Squartini • Yacine Benhizia
}

Received: 11 August 2013 / Accepted: 24 October 2013

(C) Springer-Verlag Berlin Heidelberg and the University of Milan 2013 respiratory and cardiac infections in humans. Whereas no culturable rhizobia and alike could be obtained on plates, PCR-based culture-independent approaches revealed in both plants the presence of a Mesorhizobium sp., which in $H$. perrauderianum was identical to isolates nodulating other legumes from Africa, European Mediterranean countries, and Asia, while in $H$. naudinianum it bore a single nucleotide polymorphism which is so far unique for any observed mesorhizobia. Data from the microsymbionts appear to suggest interesting clues to interpret the evolutionary ecology of their host plants.

\section{Keywords Hedysarum naudinianum · Hedysarum} perrauderianum $\cdot$ Mesorhizobium $\cdot$ Root nodules $\cdot$ Algeria $\cdot$ Endophytic bacteria $\cdot$ Endemic legumes $\cdot$ SNP

\section{Introduction}

Département de Microbiologie, Faculté des Sciences de la Nature et de la Vie, Laboratoire de Biologie Moléculaire et Cellulaire, Université Constantine 1, Route de Aïn El Bey, Constantine, Algeria

R. Rosselli $\cdot$ O. Romoli $\cdot$ E. Baldan $\cdot$ A. Tondello $\cdot$ B. Baldan Department of Biology, University of Padova, Via Ugo Bassi 58/b, 35131 Padova, Italy

M. Zanardo $\cdot$ S. Alberghini $\cdot$ A. Squartini $(\bowtie)$

Department of Agronomy Animals, Food, Natural Resources and Environment, DAFNAE, University of Padova, Viale dell'Università 16, 35020 Legnaro, Padova, Italy

e-mail: squart@unipd.it

H. Benhizia

Département de Biologie Végétale, Faculté des Sciences de la Nature et de la Vie, Laboratoire de Génétique, Biochimie et Biotechnologies Végétales, Université Constantine 1, Route de Aïn El Bey,

Constantine, Algeria
Many legume plants rely on the symbiosis with nitrogen-fixing rhizobia, and an increasing number of studies is nowadays addressing the bacterial associations of spontaneous leguminous species. Hedysarum is a genus of the Hedysareae tribe featuring about 309 species distributed worldwide. The taxon is divided in two main groups: the first includes the Alpine, Arctic, and Asiatic species ( $2 n=14$ chromosomes), while the second harbous the Mediterranean species $(2 n=16)$ (TrifiFarah and Marrakchi 2001), some of which have been repositioned in the new genus Sulla (Choi and Ohashi 2003). Within the Mediterranean set of Hedysarum, our earlier interest has been devoted to Hedysarum coronarium, which exists both as a cultivated forage crop and as wild stands. For this species, we described the new species of 
host-specific nitrogen-fixing symbiont, Rhizobium sullae (Squartini et al. 2002). Subsequently, we have investigated the bacteria in Algeria within root nodules of Hedysarum spinosissimum ssp. capitatum, H. pallidum and H. carnosum (Benhizia et al. 2004), whose occupants are dominated by endophytic gammaproteobacteria. Further. we covered two other Mediterranean wild species of Hedysarum by studying H. spinosissimum and H. glomeratum in Sardinia (Muresu et al. 2008). Subsequently. we investigated the nodule content of the relictual $H$. confertum ( $=H$. humile) (Tondello et al. 2011). In these studies. we showed the consistent nonculturability of the rhizobial symbionts and the occurrence of a vast array of opportunistic endophytes.

Within Algeria. the genus Hedysarum includes ten species, some of which are endemic, such as $H$. naudinianum and $H$. perrauderianum. The latter is moreover reported as very localized (Abdelguerfi-Berrekia et al. 1991). These two taxa are rather rare. H. naudinianum is found in the tell constantinois (mount of Bibans), in Algiers (Littoral, Tell Atlas), in Boghar. and the north of Setif (Bougaa, Ain Roua). H. perrauderianum occurs in the region of Batna and south of Setif (Abdelguerfi-Berrekia et al. 1988; Quezel and Santa 1962).

From ecological and conservational perspectives, the entire genus Hedysarum is regarded as a wealthy phytogenetic resource which is, however, increasingly endangered by progressive genetic erosion due to overgrazing, irregular rainfall. and range land contraction, particularly in dry and semi-arid areas (Trifi-Farah et al. 2002). In such scenarios, it is of primary importance to determine whether the rarity of given species could be due to their dependence on symbionts to ensure their nutritional needs. The abundance or exiguity of the suitable interactive microorganisms deeply affects soil capability to host and support plants. Both productivity and health of the crops as well as the distribution of natural vegetation are conditioned by interactions with ground microbiota, with the most significant correlation being the presence or absence of symbiotic or pathogenic microorganisms (Klironomos 2002). For these reasons, we deemed it important to cast light on the presence and identity of root nodule bacteria associated with the above-mentioned two endemic legume species thriving exclusively in Algeria and enduring harsh conditions.

\section{Materials and methods}

Plant and nodule collection

The biological material was collected in the region of Sétif $\left(36^{\circ} 12^{\prime} 0^{\prime \prime} \mathrm{N}, 5^{\circ} 24^{\prime} 0^{\prime \prime} \mathrm{E}\right)$ in the East of Algeria (Fig 1); Hedysarum naudinianum whole plants were excavated in the three sites of Bougaa $\left(00^{\circ} 00^{\prime} 00^{\prime \prime} \mathrm{N}, 5^{\circ} 04^{\prime} 60^{\prime \prime} \mathrm{E}\right)$, Ain Roua $\left(36^{\circ} 19^{\prime} 60^{\prime \prime} \mathrm{N}, 5^{\circ} 10^{\prime} 60^{\prime \prime} \mathrm{E}\right)$ and Maoklane $\left(36^{\circ} 23^{\prime} 50^{\prime \prime} \mathrm{N}\right.$, $5^{\circ} 04^{\prime} 31^{\prime \prime} \mathrm{E}$ ), while $H$. perrauderianum was gathered from Ouled Tebbene $\left(35^{\circ} 48^{\prime} 46^{\prime \prime} \mathrm{N}, 5^{\circ} 06^{\prime} 05^{\prime \prime} \mathrm{E}\right)$. All specimens were green and healthy plants. Nodules were in non-senescent, fully developed stage.

Nodule excision was carried out as described by Vincent (1970) and Beck et al. (1993). Roots were carefully cleaned and washed free of soil. Dry portions of roots with nodules were stored with $\mathrm{CaCl}_{2}$ until nodule sterilization. Plants and their root apparati are shown in Fig. 2.

\section{Nodule microscopy}

Nodules were fixed in $3 \%$ glutaraldehyde in $0.1 \mathrm{M}$ cacodylate buffer (pH 6.9) for $24 \mathrm{~h}$ at $4{ }^{\circ} \mathrm{C}$ and postfixed for $2 \mathrm{~h}$ at $4{ }^{\circ} \mathrm{C}$ in $1 \%$ osmium tetroxide in $0.1 \mathrm{M}$ cacodylate buffer, dehydrated in a graded ethanol series, and then embedded in araldite resin. Thin sections $(1 \mu \mathrm{m})$, obtained with a Reichert-Jung ultramicrotome, were stained with $1 \%$ toluidine blue for light microscopy.

\section{Bacterial isolation from the nodules}

Root portions bearing nodules were washed free of soil under running water, encaged in a fine-mesh steel holder and surface-sterilized by immersion in $95 \%$ ethanol for $20 \mathrm{~s}$, followed by $5 \%$ sodium hypochlorite for $3 \mathrm{~min}$, and then washed 7 times with sterile distilled water. Finally, nodules were transferred aseptically into sterile Petri dishes and crushed in a drop of sterile distilled water.

The nodules suspension was plated on YMA-congo red, YMA-bromo-thymol blue, and PCA- and GPA-bromo-cresol purple (Vincent 1970).

Tests to validate surface-sterilization of plant tissues, including root nodules, were performed by touching them several times on the surface of plate count agar (PCA, Difco) plates prior to isolation of the interior microbiota. The absence of colonies on these plates was a requirement to ascertain the disinfection from residual external bacteria.

$\mathrm{CaCl}_{2}$-stored dry nodules were rehydrated for $6 \mathrm{~h}$ in distilled water prior to the surface-sterilization treatment.

DNA extraction from culturable bacteria

Cells were lysed by resuspending a loopful of plate-grown isolated colonies in $50 \mu \mathrm{L}$ of lysis buffer $(0.25 \%$ sodium dodecyl sulphate, SDS $0.05 \mathrm{M} \mathrm{NaOH}$ ), followed by stirring for $60 \mathrm{~s}$ on a vortex and heating at $95{ }^{\circ} \mathrm{C}$ for $15 \mathrm{~min}$. The lysate was centrifuged for $15 \mathrm{~min}$ at $13,400 \mathrm{~g}$ and $10 \mu \mathrm{L}$ of the supernatant were mixed with $90 \mu \mathrm{L}$ of sterile water. Lysates were stored at $4{ }^{\circ} \mathrm{C}$ prior to PCR. 
Fig. 1 Algeria showing the collection sites

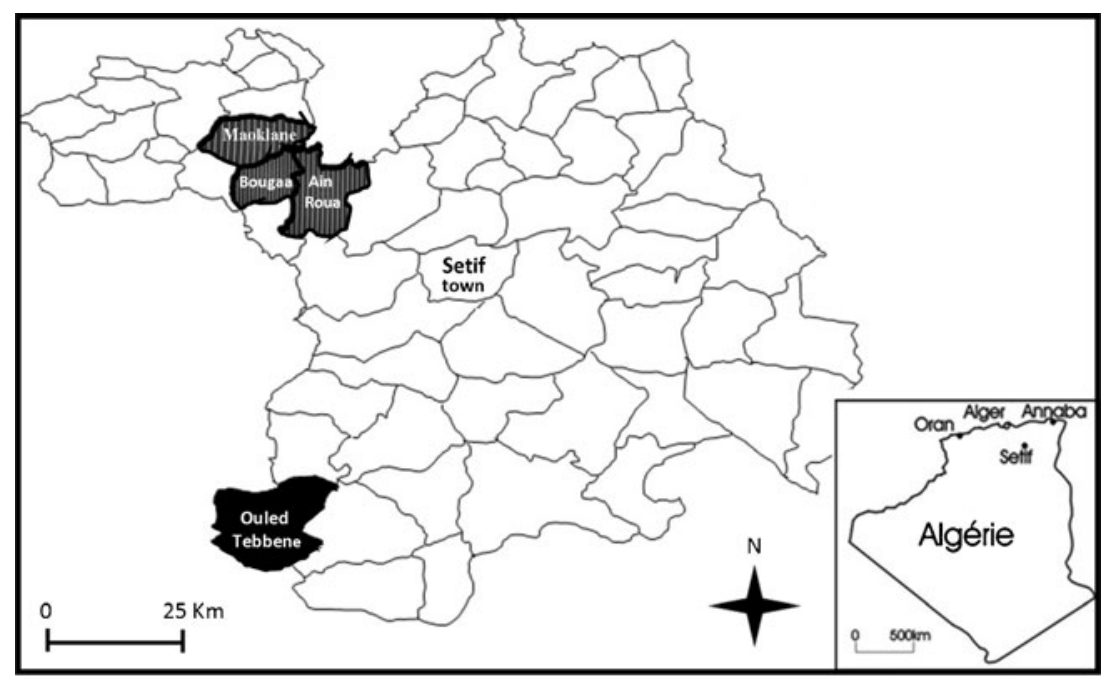

Collecting zone of $H$. naudinianum

Collecting zone of $H$. perrauderianum

\section{DNA extraction from nodules}

For direct PCR analysis, aliquots of nodule suspensions (10 $\mu \mathrm{L}$, irrespectively of original volume) were transferred to $50 \mu \mathrm{L}$ of lysis buffer, [0.25\% sodium dodecyl sulphate (SDS) $0.05 \mathrm{M} \mathrm{NaOH}]$ in a $1.5-\mathrm{mL}$ polypropylene tube, followed by stirring for $60 \mathrm{~s}$ on a vortex and heating at $95{ }^{\circ} \mathrm{C}$ for $15 \mathrm{~min}$. The lysate was centrifuged for $15 \mathrm{~min}$ at $13,400 \mathrm{~g}$ and $10 \mu \mathrm{L}$ of the supernatant were mixed with $90 \mu \mathrm{L}$ of sterile water. Lysates were stored at $4{ }^{\circ} \mathrm{C}$ prior to PCR.

\section{PCR amplification of the 16S rDNA gene}

One $\mu \mathrm{L}$ of the lysate containing the total DNA extracted from nodules was treated in a PCR BioRad I-Cycler using the two 16S rRNA gene-targeted universal bacterial primers, $63 \mathrm{~F}$ 5'CAGGCCTAACACATGCAAGTCC3') (Marchesi et al.
Fig. 2 Hedysarum naudinianum plant (a) and root nodules (b); H. perrauderianum plant (c) and root nodules (d)
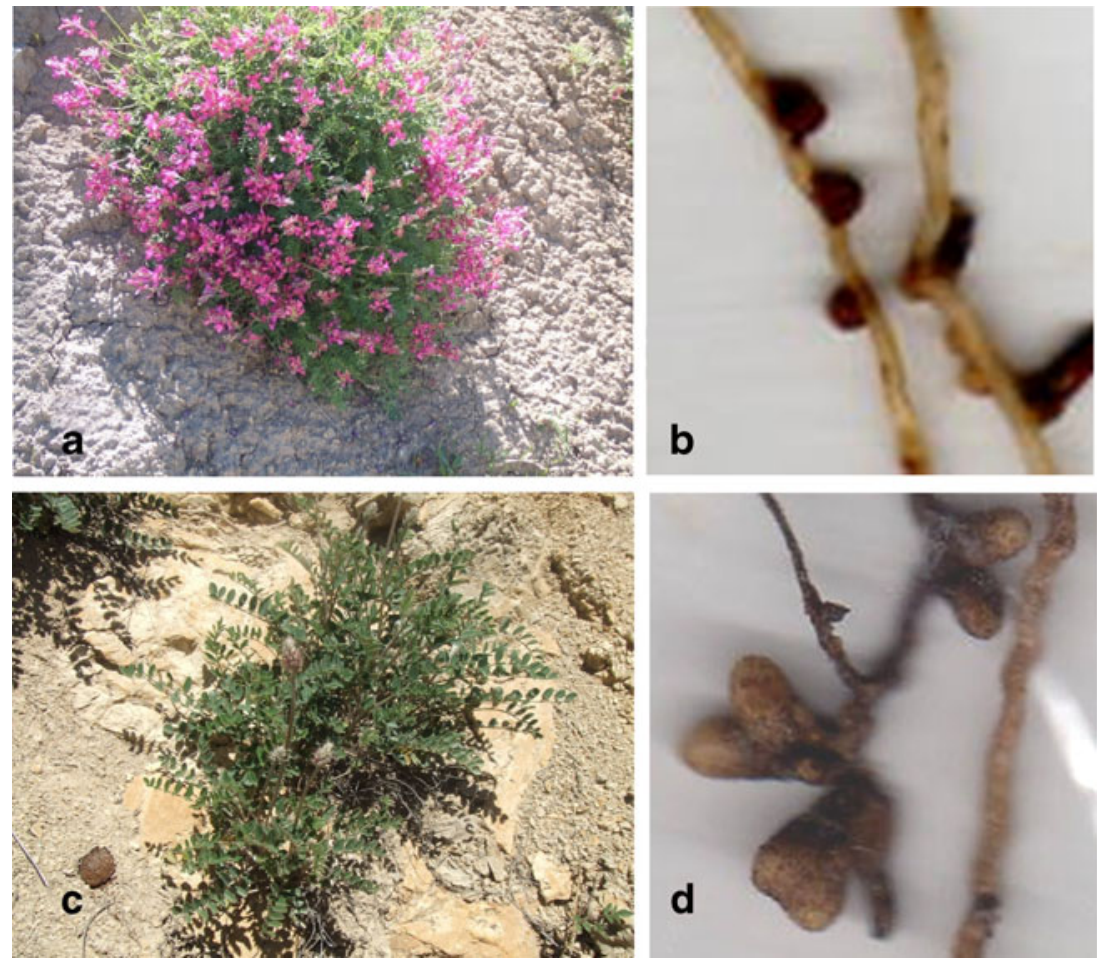
1998) and 1389R (5'ACGGGCGGTGTGTACAAGG3') (Osborn et al. 2000) in a $25-\mu \mathrm{L}$ reaction volume, using the following program: initial denaturation at $95{ }^{\circ} \mathrm{C}$ for $2 \mathrm{~min}$; 40 cycles at $95^{\circ} \mathrm{C}$ for $30 \mathrm{~s}, 55^{\circ} \mathrm{C}$ for $1 \mathrm{~min}, 72{ }^{\circ} \mathrm{C}$ for $2 \mathrm{~min}$; and a final extension at $72{ }^{\circ} \mathrm{C}$ for $10 \mathrm{~min}$. The PCR reaction mixture contained $67 \mathrm{mM}$ Tris- $\mathrm{HCl}(\mathrm{pH} \mathrm{8.8)}, 16 \mathrm{mM}$ $\left(\mathrm{NH}_{4}\right)_{2} \mathrm{SO}_{4}, 0.01 \%$ Tween-20, $2 \mathrm{mM} \mathrm{MgCl}, 0.2 \mathrm{mM}$ of each dATP, dCTP, dGTP and dTTP, $0.2 \mu \mathrm{M}$ of each primer and 0.5 U Taq DNA Polymerase (EuroTaq, EuroClone). To verify the positive reaction amplicons were loaded on a $1.5 \%$ agarose gel and run electrophoretically for $1 \mathrm{~h}$ at $110 \mathrm{~V}$. The Sybergreen-stained gel was visualized over an UV transilluminator and photographed by a Kodak DC290 digital camera.

\section{ARDRA Analysis}

Amplicons were digested overnight at $37{ }^{\circ} \mathrm{C}$ upon mixing $5 \mu \mathrm{L}$ from the $25-\mu \mathrm{L}$ reaction volume with $1 \mu \mathrm{L}$ of $C f o \mathrm{I}$ enzyme (Pharmacia, Uppsala, Sweden) and $2 \mu \mathrm{L}$ of $10 \times$ reaction buffer. Digested DNA was loaded on a $1.5 \%$ agarose gel, run electrophoretically for $3 \mathrm{~h}$ at $110 \mathrm{~V}$. The stained gel was visualized over an UV transilluminator and photographed by a Kodak DC290 digital camera. Upon ARDRA analysis, the isolates were sorted and selected for sequencing.

DNA Sequencing and bacterial molecular taxonomical analysis

One $\mu \mathrm{L}$ of the amplicon resulting from the above-described PCR amplification was mixed with $1 \mu \mathrm{L}$ containing $6.4 \mathrm{pmol}$ of the primer $63 \mathrm{~F}$ in a $0.2-\mathrm{mL}$ polypropylene tube and then dried by incubating the tube open for $15 \mathrm{~min}$ at $65{ }^{\circ} \mathrm{C}$ in an I-Cycler thermal cycler. The template and primer mix was directly used for di-deoxy-cycle DNA sequencing with fluorescent terminators (Big Dye; Perkin-Elmer/Applied Biosystems, Foster City, CA, USA) and run in an Applied Biosystems ABI Prism 3730XL automated DNA sequencer. Chromatograms were analyzed by Chromas 2.23 software (Technelysium, Tewantin, Australia). BLAST analysis (Altschul et al. 1990) against nucleotide databases was performed via the NCBI website (http://www. ncbi.nlm.nih.gov/).

DNA extraction from nodules for amplicon library cloning

Sterile nodules were resuspended in TE $1 \times(100 \mu \mathrm{L})$, smashed using a sterile pipetman tip and incubated at $95^{\circ} \mathrm{C}$ for $10 \mathrm{~min}$. Lisozyme $(1 \mathrm{mg} / \mathrm{mL})$ and SDS (1\% final concentration) were added and the solution was incubated at $37{ }^{\circ} \mathrm{C}$ for $15 \mathrm{~min}$. A proteinase-K treatment $(100 \mu \mathrm{g} / \mathrm{mL})$ was carried out at $55{ }^{\circ} \mathrm{C}$ for $1 \mathrm{~h}$.
Subsequently, a protocol adapted from the PowerSoil ${ }^{\circledR}$ DNA Isolation Kit (MO BIO, Solana Beach, CA, USA) was developed in order to increase DNA yield and purity, and after the $\mathrm{C} 3$ solution treatment, the supernatant was transferred in a new Eppendorf tube. Two extractions with phenol:chloroform:isoamyl alcohol (25:24:1) and one chloroform extraction were carried out, followed by an overnight precipitation using ammonium acetate ( $2 \mathrm{M}$ f.c.) and absolute ethanol (2.5 volumes) at $-20{ }^{\circ} \mathrm{C}$.

After incubation, samples were centrifuged at $4{ }^{\circ} \mathrm{C}$ for $40 \mathrm{~min}$ and $12,000 \mathrm{rpm}$, washed twice with $70 \% \mathrm{Et}-\mathrm{OH}$, and resuspended in $50 \mu \mathrm{L}$ of sterile distilled $\mathrm{H}_{2} \mathrm{O}$.

PCR amplification for library cloning

16S rRNA genes amplification was carried out using the universal primers described above.

A 20- $\mu$ l reaction for each sample was prepared using $0.2 \mathrm{U}$ of Phusion High-Fidelity DNA Polymerase (NEB) and the thermal cycler (iCycler, Bio Rad) was set as follows: initial denaturation at $98^{\circ} \mathrm{C}$ for $2 \mathrm{~min}, 30$ cycles at $98^{\circ} \mathrm{C}$ for $20 \mathrm{~s}$, $61{ }^{\circ} \mathrm{C}$ for $45 \mathrm{~s}, 72^{\circ} \mathrm{C}$ for $1 \mathrm{~min}$, and a final extension at $72{ }^{\circ} \mathrm{C}$ for $6 \mathrm{~min}$.

To verify the positive reaction, amplicons were loaded on a $1 \%$ agarose (SeaKem LE), run electrophoretically and purified by Agencourt AMPure XP-PCR Purification (Beckman Coulter).

PCR products were phosphorylated by a T4-PolynucleotideKinase (NEB) treatment $37^{\circ} \mathrm{C}$ for $30 \mathrm{~s}$, inactivated at $65^{\circ} \mathrm{C}$ for $20 \mathrm{~min}$.

\section{Amplicon cloning}

One $\mu \mathrm{g}$ of $\mathrm{pGEM}^{\circledR}-3 \mathrm{ff}(+)$ (Promega) was digested in a $20-\mu \mathrm{l}$ reaction by $40 \mathrm{U}$ of $S m a \mathrm{I}$ restriction enzymes (NEB), at $25^{\circ} \mathrm{C}$ for $1,5 \mathrm{~h}$ and inactivated at $65^{\circ} \mathrm{C}$ for $20 \mathrm{~min}$. Vector dephosphorylation was carried out in a $25-\mu$ reaction using $2.5 \mathrm{U}$ of Antartic Phosphatase (NEB) at $37{ }^{\circ} \mathrm{C}$ for $30 \mathrm{~min}$ followed by inactivation at $65{ }^{\circ} \mathrm{C}$ for $10 \mathrm{~min}$. Phosphorylated-PCR products and dephosphorylated-pGEM were purified by an Agencourt AMPure XP-PCR Purification (Beckman Coulter) treatment. pGEM and PCR-products (1:6 ratio) were ligated using $1 \mathrm{U}$ of a T4-DNA ligase (NEB) in a $20-\mu \mathrm{l}$ reaction, incubated at $16{ }^{\circ} \mathrm{C}$ for $16 \mathrm{~h}$ followed by inactivation at $65{ }^{\circ} \mathrm{C}$ for $20 \mathrm{~min}$. Products were cloned in E. coli DH10B. Plasmids were extracted using a FastPlasmid Mini kit (Eppendorf). A vector-screening was carried out to select clones for sequencing; a double-digestion Eco RIHin dIII (10U each) in a $20-\mu l$ reaction was performed at $37{ }^{\circ} \mathrm{C}$ for $90 \mathrm{~min}$ and inactivated at $65{ }^{\circ} \mathrm{C}$ for $20 \mathrm{~min}$. Results were verified by a $1.5 \%$ agarose (SeaKem LE) gel electrophoresis. Sanger sequencing was carried out as described above. 


\section{Results and discussion}

Nodule histology

Nodules were inspected by brightfield and transmission electron microscopy (Fig. 3). Toluidine-stained thin sections indicated that the root structures formed by $H$. naudinianum and $H$. perrauderianum are consistent with the histology of genuine legume nodules, displaying an uninfected cortex, a peripheral vascular system, and a central tissue of host cells infected to various degrees with bacteria; TEM images allow observation of details of bacterial shapes within the infected tissues. This evidence demonstrates that both species are nodulated and that their nodules bear normally invasive bacteria.

Characterization of culturable microbiota

Upon plating the content of the surface-sterilized nodules on YMA and PCA media, colonies of different kinds were observed from $H$. naudinianum, while only one morphology stemmed from $H$. perrauderianum. The recurring types were purified and characterized by DNA-based identity analyses; ARDRA profile sorting and 16S rDNA sequencing allowed the assignment of the species identities that are reported in Table 1. As already typically observed in previous studies in other wild legumes (Benhizia et al. 2004; Muresu et al. 2008; Tondello et al. 2011), no culturable rhizobia could be isolated; instead, different bacteria populated the inner tissues of these nodules. In both $H$. naudinianum and $H$. perrauderianum, we found a recurring member of the Gammaproteobacteria displaying $100 \%$ identity with both Enterobacter cloacae and E. ludwigii. Although this was the sole culturable type that we could observe in $H$. perrauderianum, the other legume, $H$. naudinianum, appears to harbor a wider spectrum of

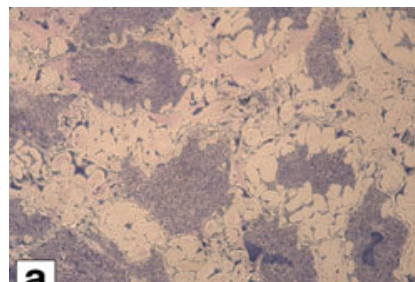

a
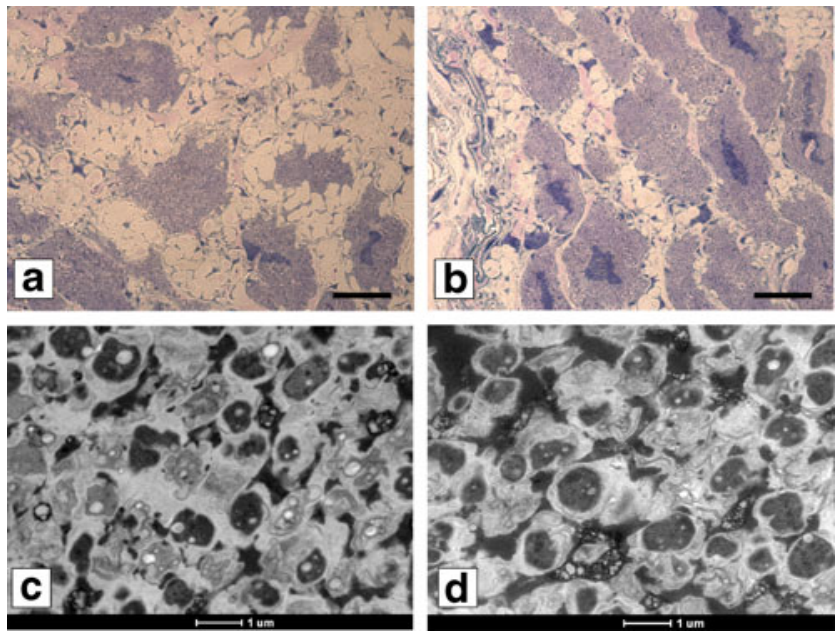

Fig. 3 Histological observations of nodule sections of $H$. naudinianum $(\mathbf{a}, \mathbf{c})$ and $H$. perrauderiuanum $(\mathbf{b}, \mathbf{d})$ in optical $(\mathbf{a}, \mathbf{b})$ and electron microscopy (c, d). Scale bars (a, b) $30 \mu \mathrm{m},(\mathbf{c}, \mathbf{d}) 1 \mu \mathrm{m}$ endophytes (Table 1) featuring lactobacilli, Gram-positives including actinobacteria, among which it is worth signaling the presence of an isolate which is $100 \%$ identical to Corynebacterium pseudodiphthericum. This taxon is classically known as the Hoffman bacillus, a resident of the human throat not proficient in causing diphtheria but reported as involved in clinical cases of pneumonia and other respiratory infections (Gorricho et al. 1996; Gutiérrez-Rodero et al. 1999; Aspiroz Sancho et al. 2002) and even suspected of being the agent of endocardytis (Dijken et al. 1950). Such occurrences of potential human or animal pathogens concealed within wild legume nodules of semiarid habitats is not new to our experience. In prior reports,we disclosed the occurrence of species known to human medicine within the nodules of $H$. spinosissimum subsp. capitatum, $H$. pallidum, and $H$. carnosum, including Enterobacter cloacae, E. kobei Escherichia vulneris, Pantoea agglomerans, Leclercia adecarboxylata, and Pseudomonas sp. (Benhizia et al. 2004). In a subsequent report, we ascertained that some of the above isolates bore phenotypic and genotypic determinants of virulence that were investigated using human cultured cells, which tested positive for the traits of cytotoxicity, vital stain exclusion, and adhesion to epithelia (Muresu et al. 2010). Antibiogram analyses also revealed a complex pattern of multiple antibiotic resistances. The data unfolded a scenario in which legume root nodules could act as a site of survival and of active multiplication for populations of mammalian pathogens whose cycle might alternate between the target animal and a number of neutral plant hosts. The worldwide diffusion of as yet uninvestigated legumes raised the concern for a general niche that could enhance the hazards posed by microorganisms of a clinical nature. The present finding of Corynebacterium pseudodiphthericumin, again occurring in the nodules of a north African spontaneous legume, further extends the case history and emphasizes the issue.

While at least six different culturable taxa could be observed to inhabit nodules of $H$. naudinianum, the same analysis on its companion species $H$. perrauderianum did not yield such a variety of species, as the sole gammaproteobacterial enterics identical to Enterobacter cloacae/Enterobacter ludwigii was found to grow from these nodules. The $16 \mathrm{~S}$ sequence of the isolate is equal to that also occurring in H. naudinianum. These kind of bacteria of the PantoeaEnterobacter group are knowingly proficient as endophytes in a number of plants (Elvira-Recuenco and Van Vuurde 2000), and are also shared in both of the Hedysarum species analyzed here, as well as in others within the Mediterranean checklist of our former studies (Muresu et al. 2008). As regards the culturable array of diversity, none of the above-described isolates belonged to the Rhizobiaceae family or to other genera of ascertained nitrogen-fixing symbionts or legumes. This led to us considering that, as observed in prior 
Table 1 Identities of bacteria associated with nodules of Hedyrasum naudinianum and H. perrauderianum as inferred by 16S rDNA sequencing and BLAST analysis in GenBank

\begin{tabular}{|c|c|c|}
\hline Identifier $^{\mathrm{a}}$ & GenBank code & Best match homologies to GenBank taxa and \% similarity \\
\hline \multicolumn{3}{|c|}{ Culture-dependent method (plate-cultured colonies) } \\
\hline \multirow[t]{2}{*}{ HnA1 } & \multirow[t]{2}{*}{ KF147863 } & Enterobacter cloacae LRC85 (JF772064) $100 \%$ \\
\hline & & Enterobacter ludwigii YPB10-1 (JQ308612)100 \% \\
\hline Hn33Ya & KF147864 & Staphylococcus sp. DG9 (JN208200) $99 \%$ \\
\hline Hn34Ya & KF147865 & Bacillus sp. NH1 (JN208177) $100 \%$ \\
\hline $\mathrm{Hn} 35 \mathrm{Ya}$ & KF147866 & Lactobacillus casei PC_CA (JN133441) $100 \%$ \\
\hline Hn36Ya & KF147867 & Rothia amarae R-36507 FR682692 99 \% \\
\hline Hn37Ya & KF147868 & Corynebacterium pseudodiphthericum CIP103420T (AJ439343) $100 \%$ \\
\hline \multirow[t]{2}{*}{ HpRA1 } & \multirow[t]{2}{*}{ KF147863 } & Enterobacter cloacae LRC85 (JF772064) $100 \%$ \\
\hline & & Enterobacter ludwigii YPB10-1 (JQ308612)100 \% \\
\hline \multicolumn{3}{|c|}{ Culture-independent method (16S amplicon cloning and bank screening) } \\
\hline \multirow[t]{4}{*}{ HnNod1 } & \multirow[t]{4}{*}{ KF147869 } & Mesorhizobium sp. (JF273844 ) Coronilla varia, China, 99 \% \\
\hline & & Mesorhizobium sp. (EU697961) Ammopiptanthus mongolicus, China, 99 \% \\
\hline & & Mesorhizobium sp. (AM748949) Anagyris foetida, Sicily, $99 \%$ \\
\hline & & Rhizobium sp. H-4 (AF279889) Hedysarum spinosissimum, Israel, 99 \% \\
\hline HnNod4 & KF147870 & Flavobacterium sp. TP-Snow-C28 (HQ327137) 98 \% \\
\hline HnNod5 & KF147871 & Caulobacter sp. HWE-A01 (JF722654) $100 \%$ \\
\hline HnNod6 & KF147872 & Afipia sp. BAC312 EU13095198\% \\
\hline HnNod7 & KF147873 & Moraxella osloensis DSM 6998 AB643599 100 \% \\
\hline \multirow[t]{4}{*}{ HpNod2 } & \multirow[t]{4}{*}{ KF147875 } & Mesorhizobium sp. (JF273844 ) Coronilla varia, China, 100 \% \\
\hline & & Mesorhizobium sp. (EU697961) Ammopiptanthus mongolicus, China, $100 \%$ \\
\hline & & Mesorhizobium sp. (AM748949) Anagyris foetida, Sicily, 100 \% \\
\hline & & Rhizobium sp. H-4 (AF279889) Hedysarum spinosissimum, Israel, 100 \% \\
\hline HpNod1 & KF147874 & Acinetobacter sp. uncultured, clone ASC753 (JQ775355) $99 \%$ \\
\hline HpNod3 & KF147876 & Phyllobacterium brassicacearum MR4 (EF581126) 99 \% \\
\hline
\end{tabular}

${ }^{\mathrm{a}}$ Isolates from $H$. naudinianum are coded with the prefix $\mathrm{Hn}$; those from $H$. perrauderianum with the prefix $H p$

reports (Muresu et al. 2008), these two legumes could also harbor non-culturable rhizobia along with various culturable endophytes. As, when dealing with other Mediterranean wild species, we had been successful in the direct 16S rDNA amplification of rhizobium (Muresu et al. 2008, 2011; Tondello et al. 2011; Ourarhi et al. 2011), we performed several attempts with nodules of the two species described here but in no case could we get any readable sequence with this approach, the PCRs resulting in either no amplification or mixed chromatograms. Such limitation led to a different strategy and, in order to circumvent the problem, we cloned amplicons in plasmid vectors, transforming $E$. coli and screening the libraries. This approach led to us uncovering another portion of diversity in which we found frequent clones whose sequence was consistent with members of the rhizobiaceae, namely Mesorhizobium sp. which was found in both plants. Under the existing evidence, these are to be considered the putative true symbionts of both plants, and show identities to other mesorhizobia reported in different legumes from Mediterranean to Far East locations (Table 1).
Different taxa including Caulobacter, Afipia and Moraxella were present within $H$. naudinianum nodules, while Acinetobacter and Phyllobacterium were in $H$. perrauderianum.

As regards the two sequences of Mesorhizobium found in $H$. naudinianum and $H$. perrauderianum, it is worth reporting that these differ from each other by a single nucleotide. For this reason, the identities with other mesorhizobia are in one case $99 \%$ and in the other $100 \%$. As these cases of single mismatching could be suspected of being artifacts due to sequencing errors in nucleotide attribution for poorly resolved fluorescence peaks, we repeated the sequencing twice and inspected the corresponding regions of the chromatograms whose output was clear, and consistently carried a genuine difference in a nucleotide ( $\mathrm{G}$ for $\mathrm{T}$ ) which corresponds to position 238 of the reference $E$. coli 16S rRNA gene.

Interestingly, the presence of a $\mathrm{G}$ in that position for the bacterium in $H$. perrauderianum is conserved not only among the four examples of mesorhizobia from Anagyris foetida, Coronilla varia, Ammopiptanthus mongolicum, and 
Hedysarum spinosisismum reported in Table 1 but also in those found in Sardinia (Muresu et al. 2008) within Hedysarum glomeratum, (DQ457611), Hippocrepis unisiliquosa (DQ457615), Scorpiurus muricatus DQ457619, Tetragonolobus purpureus DQ457620, and Psoralea bituminosa (DQ457618), all of which carry the $\mathrm{G}$ at position 238. Therefore, the sequence of the Mesorhizobium within $H$. naudinianum bears a mutation which is unique and originates a single nucleotide polymorphism (SNP) which stands out as indicative of an interesting separation from other mesorhizobia occurring throughout different continents, which instead all share the alternative version of the sequence. The uniqueness of the bacteria associated to this Algerian botanical endemism suggests that its origin could be that of a neo-endemism (originating locally possibly by hybridization with other species) rather than a paleo-endemism (formerly more extended but presently relictual and extinct elsewhere), which could instead be the case of $H$. perrauderianum whose symbiont is still also present in legumes of far distant ranges and different tribes. This finding and the possible speculations exemplify an additional element of usefulness in studying bacterial symbionts as keys to interpret their host plants' evolutionary biology.

\section{References}

Abdelguerfi-Berrekia R, Abdelguerfi A, Bounaga N, Guittonneau GG (1988) Contribution à l'étude des espèces spontanées du genre Hedysarum L. en Algérie. I- Etude auto écologique. Ann Inst Nat Agro El-Harrach 12:191-219

Abdelguerfi-Berrekia R, Abdelguerfi A, Bounaga N, Guittonneau GG (1991) Répartition des espèces spontanées du genre Hedysarum selon certains facteurs du milieu en Algérie. Fourrages 126:187-207

Altschul SF, Gish W, Myers EW, Lipman DJ (1990) Basic local alignment search tool. J Mol Biol 215:403-410

Aspiroz Sancho C, Agustín Berne A, Navarro Pardos C, Sañudo Blasco B, Teller JP (2002) Pneumonia caused by Corynebacterium pseudodiphteriticum, an entity worth knowing. An Med Interna 19:463-465

Beck DP, Materon LA, Afandi F (1993) Pratical Rhizobium- Legume Technology Manual. ICARDA, Syria

Benhizia Y, Benhizia H, Benguedouar A, Muresu R, Giacomini A, Squartini A (2004) Gamma proteobacteria can nodulate legumes of the genus Hedysarum. Syst Appl Microbiol 27:462-468

Choi BH, Ohashi H (2003) Generic criteria and infrageneric system for Hedysarum and related genera (Papilionoideae e Leguminosae). Taxon 52:567-576

Dijken B, Van Wermeskerken J, Beute A (1950) Subacute bacterial endocarditis, probably caused by Corynebacterium pseudodiphthericum (Hofmann's bacillus). Ned Tijdschr Geneeskd 94:2081-2088
Elvira-Recuenco M, van Vuurde JWL (2000) Natural incidence of endophytic bacteria in pea cultivars under field conditions. Can J Microbiol 46:1036-1041

Gorricho J, Cruz Villuendas M, Remacha MA, Seoane A (1996) Pneumonia by Corynebacterium pseudodiphthericum. Enferm Infecc Microbiol Clin 14:632-633

Gutiérrez-Rodero F, Ortiz de la Tabla V, Martínez C, Masiá MM, Mora A, Escolano C, González E, Martin-Hidalgo A (1999) Corynebacterium pseudodiphtheriticum: an easily missed respiratory pathogen in HIV-infected patients. Diagn Microbiol Infect Dis 33:209-216

Klironomos JN (2002) Feedback with soil biota contributes to plant rarity. and invasiveness in communities. Nature 417:67-70

Marchesi JR, Sato T, Weightman AJ, Martin TA, Fry JC, Hiom SJ, Wade WG (1998) Design and evaluation of useful bacterium-specific PCR primers that amplify genes coding for bacterial 16S rRNA. Appl Environ Microbiol 64:795-799

Muresu R, Polone E, Sulas L, Baldan B, Tondello A, Delogu G, Cappuccinelli P, Alberghini S, Benhizia Y, Benhizia H, Benguedouar A, Mori B, Calamassi R, Dazzo FB, Squartini A (2008) Coexistence of predominantly nonculturable rhizobia with diverse, endophytic bacterial taxa within nodules of wild legumes. FEMS Microbiol Ecol 63: 383-400

Muresu R, Maddau G, Delogu G, Cappuccinelli P, Squartini A (2010) Bacteria colonizing root nodules of wild legumes exhibit virulenceassociated properties of mammalian pathogens. Antonie Van Leeuwenhoek 97:143-153

Muresu R, Polone E, Sorbolini S, Squartini A (2011) Characterization of endophytic and symbiotic bacteria within plants of the endemic association Centaureetum horridae. Mol Plant Biosyst 145:478-484

Osborn AM, Moore ERB, Timmis KN (2000) An evaluation of terminalrestriction fragment length polymorphism (T-RFLP) analysis for the study of microbial community structure and dynamics. Environ Microbiol 2:39-50

Ourarhi M, Abdelmoumen H, Guerrouj K, Benata H, Muresu R, Squartini A, Missbah El Idrissi M (2011) Colutea arborescens is nodulated by diverse rhizobia in Eastern Morocco. Arch microbiol 193:115-24

Quezel P, Santa S (1962) Nouvelle flore de l'Algérie et des régions désertiques méridionales. CNRS, Paris

Squartini A, Struffi P, Döring H, Selenska-Pobell S, Tola E, Giacomini A, Vendramin E, Velázquez E, Mateos PF, Martínez-Molina E, Dazzo FB, Casella S, Nuti MP (2002) Rhizobium sullae sp. nov. (formerly 'Rhizobium hedysari'): the root-nodule microsymbiont of Hedysarum coronarium L. Int J Syst Evol Microbiol 52:1267-1276

Tondello A, Villani M, Alessandrini A, Baldan B, Squartini A (2011) Identification of the root nodule symbiont of the rare legume species Hedysarum confertum Desf. (Hedysarum humile L.) in its Italian relictual site. Plant Biosytems 145:901-905

Trifi-Farah N, Marrakchi M (2001) Hedysarum phylogeny mediated by RFLP analysis of nuclear ribosomal DNA. Gen Res Crop Evol 48: 339-345

Trifi-Farah N, Baatout H, Boussaid M, Combes D, Figier J, HannachiSalhi A, Marrakchi M (2002) Evaluation des ressources génétiques des espèces du genre Hedysarum dans le bassin méditerranéen. Plant Genet Resour Newslett 130:1e6

Vincent JM (1970) The manual for the practical study of root nodule bacteria. Blackwell, Oxford 